\title{
Antibody therapy for histoplasmosis
}

\author{
Joshua D. Nosanchuk ${ }^{1,2}$ *, Rosely M. Zancopé-Oliveira ${ }^{3}$, Andrew J. Hamilton $^{4}$ and Allan J. Guimarães ${ }^{5}$ \\ Department of Medicine, Albert Einstein College of Medicine, Bronx, NY, USA \\ ${ }^{2}$ Department of Microbiology and Immunology, Albert Einstein College of Medicine, Bronx, NY, USA \\ ${ }^{3}$ Laboratório de Micologia, Setor de Imunodiagnóstico, Instituto de Pesquisa Clínica Evandro Chagas, Fundação Oswaldo Cruz, Rio de Janeiro, Brazil \\ ${ }^{4}$ Dermatology Laboratory, Guys Hospital, Kings College, London, UK \\ ${ }^{5}$ Departmento de Imunologia, Instituto de Microbiologia Professor Paulo de Góes, Universidade Federal do Rio de Janeiro, Rio de Janeiro, Brazil
}

Edited by:

Carlos Pelleschi Taborda, University of São Paulo, Brazil

Reviewed by:

Leonardo Nimrichter, Federal

University of Rio de Janeiro, Brazil

Beatriz L. Gomez Giraldo, Corporacion

Para Investigaciones Biologicas,

Colombia

*Correspondence:

Joshua D. Nosanchuk, Albert Einstein College of Medicine, 1300 Morris

Park Avenue, Bronx, NY 10461, USA

e-mail: josh.nosanchuk@einstein.

yu.edu
The endemic human pathogenic fungus Histoplasma capsulatum is a major fungal pathogen with a broad variety of clinical presentations, ranging from mild, focal pulmonary disease to life-threatening systemic infections. Although azoles, such as itraconazole and voriconazole, and amphotericin B have significant activity against $H$. capsulatum, about 1 in 10 patients hospitalized due to histoplasmosis die. Hence, new approaches for managing disease are being sought. Over the past 10 years, studies have demonstrated that monoclonal antibodies (mAbs) can modify the pathogenesis of histoplasmosis. Disease has been shown to be impacted by mAbs targeting either fungal cell surface proteins or host co-stimulatory molecules. This review will detail our current knowledge regarding the impact of antibody therapy on histoplasmosis.

Keywords: Histoplasma capsulatum, histoplasmosis, antibody, histone 2B, heat shock protein 60 , M antigen, co-stimulation

\section{INTRODUCTION}

The most commonly encountered endemic mycoses in the Americas are due to Histoplasma capsulatum, Blastomyces dermatitidis, Paracoccidioides brasiliensis, and Coccidioides immitis/posadasii (Lockhart et al., 2009; Prado et al., 2009). As is the case in other endemic fungi, $H$. capsulatum infection is typically acquired by inhalation of fungal propagules after disturbances of contaminated soil or excreta (Guimaraes et al., 2006). The clinical manifestation of the disease range from asymptomatic infection or a mild influenza-like illness to a disseminated sepsis form that may involve virtually any tissue (Meloan, 1952; Goodwin and Des Prez, 1978; Fojtasek et al., 1994; Bradsher, 1996). These manifestations depend mainly on the magnitude of exposure (i.e., the number of fungal particles inhaled), the immunological status of the host (i.e., patients with AIDS or individuals receiving steroids or chemotherapy), and the virulence of the infective strain, indicating that environmental and genetic factors influence the manifestation of disease (Goodwin et al., 1981; Kauffman, 2007). The vast majority of infected persons have either no symptoms or a very mild illness that is never recognized as being histoplasmosis (Wheat et al., 2007). In fact, 95-99\% of the primary infections are not recognized or detected in immunologically normal hosts in endemic areas (Saliba and Beatty, 1960; Isbister et al., 1976; Goodwin et al., 1981). Although the majority of symptomatic infections follow primary exposures to H. capsulatum, reactivation of latent infection can result in significant disease, particularly in the setting of immunosuppression (Kauffman, 2007). Furthermore, reactivation disease can be developed in liver transplant recipients with disease originating from latent infections in the transplanted organs (Limaye et al., 2000). Additionally, reactivation histoplasmosis has increasingly occurred in patients receiving anti-cytokine therapies, especially inhibitors of
INF- $\gamma$ and TNF- $\alpha$ (Deepe, 2005; Deepe et al., 2005; Scheckelhoff and Deepe, 2005).

As infection with $H$. capsulatum is not a mandatory reportable event, the actual incidence of clinically significant histoplasmosis is not known. Epidemiological studies have estimated that 500,000 individuals acquire $H$. capsulatum annually in the USA and over $80 \%$ of young adults in endemic areas have been infected with the fungus (Edwards et al., 1969). A national survey of hospital discharge diagnoses from 2002 identified 3,370 patients hospitalized for histoplasmosis in the USA with a crude mortality rate of $8 \%$ (Chu et al., 2006). Notably only $14 \%$ of the patients were immunocompromised and this percentage was similar in those who died. Given the nature of the survey, it only represented a "fraction of the burden of all morbidity and mortality" (Chu et al., 2006) related to $H$. capsulatum. This study also documents that hospital charges for the identified patients were well over $\$ 100$ million. Hence, histoplasmosis is a significant and costly cause of morbidity and mortality in otherwise healthy individuals and in immunodeficient patients. Despite the potency of current antifungal drugs, they nevertheless fail to prevent mortality in nearly 1 in 10 patients hospitalized with histoplasmosis.

Although $H$. capsulatum has previously been considered to consist of three varieties, capsulatum, duboisii, and farciminosum (Darling, 1906; Dodd and Thompkins, 1934; Medoff et al., 1987), recent molecular work has shown that these distinctions are phylogenetically meaningless, but instead, there are genetically distinct geographical populations or phylogenetic species (Kasuga et al., 2003). H. capsulatum is a dimorphic fungal pathogen with two distinct morphological forms, filamentous and yeast, depending on the nutritional factors and temperature (Maresca and Kobayashi, 1989). H. capsulatum is found in nature primarily as a saprophytic mold, and exists in soils enriched with organic nitrogen sources 
such as animal excrements, or when grown in the laboratory at less than $35^{\circ} \mathrm{C}$ (Emmons, 1950, 1956a,b; Zeidberg et al., 1952; Alteras, 1966; Emmons et al., 1966; Disalvo et al., 1970; Smith, 1971a,b). The mold form is composed of hyaline septate hyphae that produce two different asexual reproduction structures, macroconidia and microconidia. The microconidia are the purported infectious propagule, as their size, $2-6 \mu \mathrm{m}$, is well suited for deposition into distal alveoli. Upon entry to a susceptible host, the microconidia rapidly convert to the pathogenic single, budding yeast-like form, which can also be cultivated in laboratory medium at $37^{\circ} \mathrm{C}$.

As a facultative intracellular parasite, the interaction of H. capsulatum with macrophage cells is a critical component of the host response to infection (Newman, 2005) and is a complex and obscure phenomenon. Heat shock protein 60 (Hsp60) is the major H. capsulatum surface ligand that engages CD11b/CD18 (CR3) integrin on the surface of phagocytes resulting in phagocytosis (Long et al., 2003; Habich et al., 2006). H. capsulatum yeasts have critical interactions with inflammatory neutrophils, and with dendritic cells (DCs) in the lung and other organs. Indeed, recent new evidence suggests that DCs may be the key antigen-presenting cells that initiate cell-mediated immunity (Deepe et al., 2008). $H$. capsulatum yeast cells must survive and/or subvert the hostile antimicrobial environmental within phagocytes (Allendoerfer et al., 1997), including fungicidal mechanisms such as reactive oxygen species and products of the nitric oxide synthase (NOS) pathway (Eissenberg and Goldman, 1987). The yeast form actively inhibits phagolysosomal fusion, thereby preventing exposure to the acidic hydrolytic enzymes of the lysosomes. H. capsulatum also prohibits accumulation of vacuolar ATPase, which is important for proton accumulation in phagosomes, and the fungus can actively alkalinize phagosomal pH to 6.5 (Strasser et al., 1999). Within the phagocytic cells, viable yeast may travel to hilar and mediastinal lymph nodes where they gain access to the blood circulation for dissemination to various organs, such as the liver and spleen (Wheat and Kauffman, 2003).

The therapeutic approach to patients with histoplasmosis is well documented in a 2007 "practice guideline" by the Infectious Diseases Society of America (Wheat et al., 2007). Azole drugs, such as itraconazole and voriconazole, and amphotericin B are the drugs of choice for clinically significant disease. However, as detailed above, these potent therapeutics fail to prevent mortality in a significant proportion $(\sim 10 \%)$ of hospitalized patients. Additionally, the antifungal agents are given for protracted periods or even life-long in settings of ongoing immunocompromise. Hence, new therapeutic approaches have been investigated. One of the different avenues of study has been the application of antibodies to modify the pathogenesis of histoplasmosis.

\section{ANTIBODIES IN HISTOPLASMOSIS}

Passive immunization with polyclonal antibodies is controversial for mycoses (Louria and Kaminski, 1965). However, there is a growing consensus that antibodies collaborate with phagocytic cells and T cells for the enhancement of the immune response during systemic mycosis (Yuan et al., 1997; Vecchiarelli and Casadevall, 1998; Huffnagle and Deepe, 2003). Moreover, experiments with polyclonal sera have produced conflicting results that have raised questions regarding antibody efficacy in fungal disease (Louria and Kaminski, 1965; Mukherjee et al., 1992; Casadevall, 1998). In the 1970s, adoptive transfer experiments of serum from mice immunized with Hc ribosomes or live yeast cells failed to protect mice infected with the fungus, whereas transfer of filtered spleen or peritoneal cells from the immunized animals were protective (Tewari et al., 1977).

Recently, studies with monoclonal antibodies (mAbs) strongly have suggested that divergent results obtained with polyclonal antibodies preparations may be a result of the relative proportions of protective, non-protective, and inhibitory antibodies in immune sera (Dromer et al., 1987; Mukherjee et al., 1992) since animal experiments with $\mathrm{mAbs}$ to the capsular polysaccharide of Cryptococcus neoformans $(\mathrm{Cn})$ have revealed the existence of protective, non-protective, and disease-enhancing mAbs. A protective $\mathrm{mAb}$ may even have a reduced efficacy if administered in high amounts, due to a prozone-like effect (Taborda and Casadevall, 2001; Taborda et al., 2003). In addition, protective efficacy of mAbs is determined by several variables including pathogen inoculum (Taborda et al., 2003), genetic background of both microbe (Mukherjee et al., 1995b) and host (Lendvai and Casadevall, 1999; Zaragoza et al., 2007), host immunological status (Yuan et al., 1997), both epitope specificity and isotype of mAb (Mukherjee et al., 1992, 1995a), timing of antibody administration (Casadevall, 1998; Casadevall et al., 1998), and route of infection (Briles et al., 1992a,b).

The antibody response to infection with $H$. capsulatum has been characterized. In humans, infection induces an increase in IgM by 2 weeks, followed by rising titers of IgA and IgG (Chandler et al., 1969). The IgG fraction contains complement-fixing and precipitating antibodies (Chandler et al., 1969). Murine experiments show that Histoplasma-specific serum immunoglobulin levels peak by day 21 (Fojtasek et al., 1993). Studies on the inflammatory reactions in the lungs of mice infected with $H$. capsulatum demonstrate that the number of B cells increase in the first week of infection, albeit to a lesser degree than other myeloid cells lines (Fojtasek et al., 1993; Cain and Deepe, 1998). Subsequently, the number of $\mathrm{B}$ cells continues to increase as other myeloid lines decrease (Cain and Deepe, 1998). The number of B cells in the spleen does not significantly change until the end of the second week of infection when all cell subsets nearly double (Fojtasek et al., 1993). In histoplasmosis, the current paradigm for host control of infection relies most heavily on activation of cellular immunity, since, in the absence of effector cells, progressive disease with dissemination occurs (Allendorfer et al., 1999). However, Blymphocytes can impact histoplasmosis. Depletion of CD4+ and CD8 + T cells in B-lymphocyte knockout mice induced a markedly higher $H$. capsulatum burden in organs when compared with $\mathrm{T}$ cell depletion in wild-type animals in a secondary histoplasmosis model (Allen and Deepe, 2006), corroborating previous studies showing that antibodies can modify the pathogenesis of mycoses (Pirofski and Casadevall, 1996; Casadevall, 1998; Casadevall et al., 1998).

\section{HISTOPLASMA CAPSULATUM FUNGAL CELL SURFACE: TARGETS FOR ANTIBODY}

The fungal cell wall is rich in targets for the immune system (Nimrichter et al., 2005). As with most other pathogenic fungi, $H$. 
capsulatum possesses a rigid, polysaccharide composed cell wall structure, with four different glycans: soluble galactomannan, $\alpha$ 1,3-glucan, $\beta$-1,3-glucan, and a fibrillar chitin skeleton (Domer, 1971; San-Blas et al., 1978). Displayed on the surface are a variety of proteins that have been associated with virulence or utilized in diagnosis of the fungus (Figure 1). MAbs have been generated that bind $H$. capsulatum cell wall antigens, including melanin (Nosanchuk et al., 2002), histone 2B (Nosanchuk et al., 2003), Hsp60 (Guimaraes et al., 2009), M antigen (Guimaraes et al., 2008), and a 70-kDa protein (Lopes et al., 2010).

\section{HISTONE 2B}

Immunization with heat-killed $H$. capsulatum yeast cells resulted in the generation of a panel of IgM isotype mAbs that specifically bound cell surface expressed histone 2B (Nosanchuk et al., 2003). Although the identification of histone $2 \mathrm{~B}$ as a cell surface antigen was surprising, histones are increasingly described on the cell surface of diverse host cells as well as pathogens; such as the cell surface of Mycobacterium leprae (Pessolani et al., 1993; Marques et al., 2000, 2001) and Mycobacterium smegmatis (Pethe et al., 2001) that are associated with binding to host cells and, specifically in the case of M. leprae, cell invasion (Shimoji et al., 1999). The administration of the IgM mAbs to $H$. capsulatum histone $2 \mathrm{~B}$ was hindered by the large molecular weight of the mAbs and the difficulty with their entry into the alveolar space. However, co-incubation of mAb with $H$. capsulatum yeast cells prior to infection of mice revealed that the mAbs reduced the severity of disease. The protective effect was augmented by the administration of sub-inhibitory concentrations of amphotericin B, which stimulates host immune responses by engaging TLR2 and CD14 (Sau et al., 2003). Overall, the IgM mAbs to histone 2B reduced fungal burdens, decreased pulmonary inflammatory damage, and prolonged murine survival.
The protective effect of these mAbs was associated with an alteration in the intracellular fate of $H$. capsulatum (Nosanchuk et al., 2003; Shi et al., 2008). The mAbs reduced the capacity of the fungus to replicate intracellularly. Although $H$. capsulatum typically tightly regulates the phagosomal $\mathrm{pH}$ of macrophages, yeast opsonized with $\mathrm{mAb}$ to histone $2 \mathrm{~B}$ were unable to maintain a neutral $\mathrm{pH}$ in their host macrophage cells. The inability to regulate the $\mathrm{pH}$ resulted in fungal cell killing, increased processing of fungal antigens and increased T cell activation (Shi et al., 2008).

\section{HEAT SHOCK PROTEIN 60}

As described above, Hsp60 is the surface protein that is the major ligand that mediates attachment of $H$. capsulatum to macrophage CR3 (CD11b/CD18; Long et al., 2003). Hsp60 is also an immunodominant antigen expressed on the surface of $H$. capsulatum yeasts and is able to induce protective immunity upon vaccination (Deepe et al., 1996; Deepe and Gibbons, 2002; Scheckelhoff and Deepe, 2002). Using recombinant Hsp60, we generated IgG isotype mAbs (Guimaraes et al., 2009). Interestingly, IgG2a and IgG1 mAbs to Hsp60 were protective whereas a IgG2b was disease-enhancing. Protection was characterized by a reduction of fungal burden, decreased tissue damage, and prolongation of survival. Cytokine analyses revealed that the protective mAbs induced a strong Th1-type host response. Notably, the IgG2b recognized the same region on the protein to which a protective IgG1 also bound in a competitive manner, suggesting that protection was regulated by isotype. This finding was supported by data from mice treated with methamphetamine that developed significant increases in their IgG2b levels and also had accelerated and exacerbated histoplasmosis (Martinez et al., 2009).

As with the mAbs to histone $2 \mathrm{~B}$, the protective mAbs to Hsp60 modified the intracellular fate of the yeast cells. Phagosomal

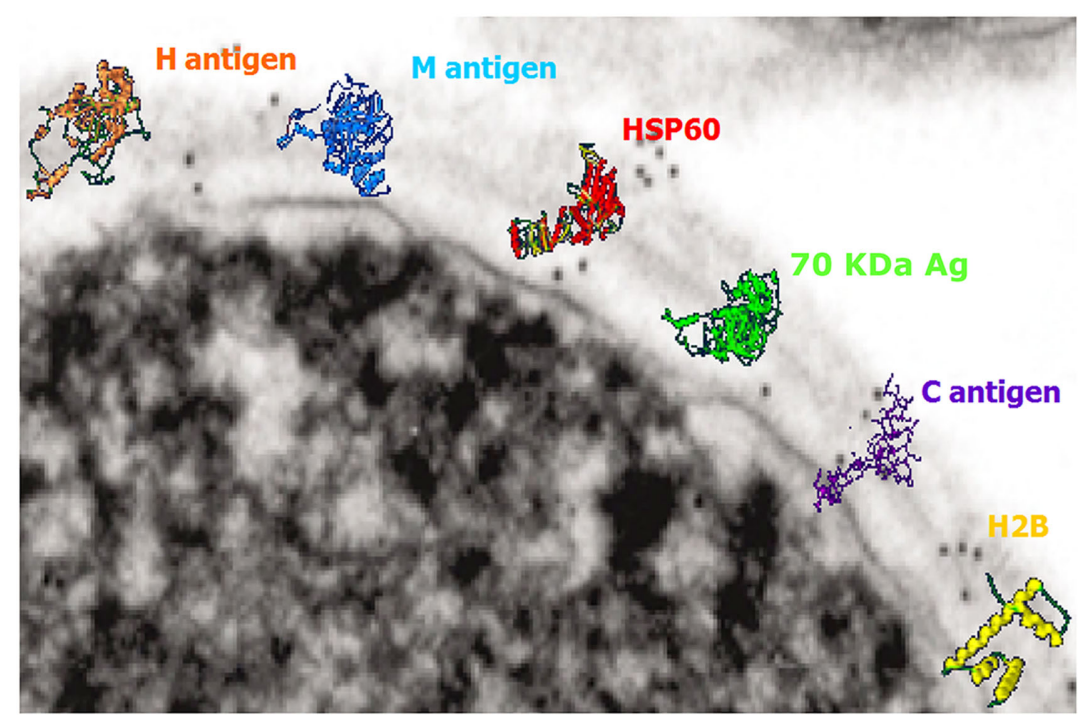

FIGURE 1 | Transmission electron micrograph of the surface of a $H$. capsulatum yeast cell with overlaying cartoons depicting the hypothetical structures of the $\mathrm{H}$ antigen, $\mathrm{M}$ antigen, heat shock protein 60, $70 \mathrm{kDa}$ antigen, $\mathrm{C}$ antigen, and histone $2 \mathrm{~B}$. The antigen structures are based on molecular modeling as described in Guimaraes et al. (2008). 
maturation was significantly increased in the presence of the protective mAbs and this correlated with a reduction in intracellular yeast cell survival. In contrast, yeast cultured with the diseaseenhancing IgG2b mAb replicated at an enhanced rate compared to controls.

Interestingly, the protective mAbs were noted to induce aggregation of $H$. capsulatum yeast cells (Guimaraes et al., 2011a). Agglutination of yeast cells caused by antibodies had been reported previously for C. neoformans (Kozel and McGaw, 1979). However, agglutination was evaluated with IgG-opsonized strain 602 of C. neoformans, by using a monospecific antiserum to IgG heavy chains, in order to confirm association of IgG antibodies to the yeast and specifically determine that these molecules were binding directly at the yeast surface. With $H$. capsulatum we observed that agglutination occurred only when cells are brought together due to a result of a Brownian movement during which cellular collision permits interaction. However, the surface of $H$. capsulatum yeast is typically negatively charged due to the high amounts of $\alpha-1,3$-glucans on the cell wall. The negative charge increases the electrostatic potential surrounding the cells leading to repulsion between cells. H. capsulatum yeast aggregation was an effect of concentration, but the magnitude of aggregation efficiency was dependent on the dissociation constant of each mAb characterized. Additionally, we used an optical tweezer to measure real-time interactions between single cells in the presence of opsonins and found a correlation of time for aggregation (characteristic time) and binding constant, with the protective mAb being more effective than the non-protective mAb. Interestingly, blockade of CR3 receptors resulted in an additional drop of phagocytosis rate of larger aggregates, suggesting a cooperative function of Fc and CR3 receptor for the phagocytosis of large particles. Overall, it is unclear what the impact of agglutination potential of the antibodies is during infection. However, it is possible that the antibodies may keep replicating cells agglutinated, which can reduce the dissemination of the fungus, and these clusters of cells may be more effectively targeted by host responses.

We have also recently demonstrated that Hsp60 is involved in the presentation of a diverse range of proteins on the fungal cell surface, including proteins associated with oxidative stress responses (Guimaraes et al., 2011c). Hence, the binding of Hsp60 by antibody may dysregulate the chaperone functions of the protein. Disruption of this interactome, especially during stress response conditions, could impact the capacity of the fungus to cause disease.

\section{ANTIGEN}

The $\mathrm{M}$ antigen is a glycoprotein that is well known as a diagnostic antigen for acute histoplasmosis as it induces the first precipitins during disease (Pizzini et al., 1999). We have documented that live fungal cells secrete only small amounts of the protein and interestingly, we demonstrated that the $M$ antigen was also expressed at the $H$. capsulatum cell surface and that it functions as a catalase (Guimaraes et al., 2008). In the course of this study, we produced three mAbs to the $M$ antigen, one IgM and two IgG2a isotype mAbs. Opsonization of $H$. capsulatum with the IgM or IgG2a mAbs to the $\mathrm{M}$ antigen enhances yeast cell phagocytosis by macrophages and two of the three mAbs also promote host cell cidal activity (Figures 2A,B). All three mAbs also altered the pathogenesis of experimental murine histoplasmosis as mice challenged with opsonized yeast cells uniformly survived a lethal challenge with $H$. capsulatum (Figure 2C).

\section{0 kDa ANTIGEN}

In addition to the fact that the IgG2b mAb to Hsp60 was not protective, we have demonstrated that an IgG1 mAb specific for a 70-kDa cell surface antigen was non-protective (Lopes et al., 2010). The mAb was previously shown to be highly specific for $H$. capsulatum and is a candidate for use in the serological diagnosis and management of histoplasmosis (Gomez et al., 1997, 1999). The finding that the IgG1 to the $70-\mathrm{kDa}$ antigen was non-protective indicates that isotype is not the only determinant for a protective response, but that the antigen target can also influence the outcome of disease.

\section{DISCUSSION}

The incidence of clinically relevant mycoses is rising, mainly due to recent advances in modern medicine, including the use of intravascular devices, broad spectrum antibiotics, organ transplantation, the use of chemotherapeutic and anti-inflammatory drugs, and the increasing number of individuals with HIV infection (Pfaller and Diekema, 2010). Given the difficulties in combating severe fungal diseases with our current antifungal medications, novel approaches, including administration of mAbs, are being pursued. Studies with antibody and $H$. capsulatum reveal that protective and non-protective antibodies exist. This finding is also extremely relevant to vaccine development, as an adverse outcome of vaccination might be the generation of diseaseenhancing antibodies, even if the latter are a subset of those induced.

The protective mAbs to $H$. capsulatum identified to date mediate protection by modifying the intracellular fate of the yeast cells. H. capsulatum is remarkable for its capacity to tightly regulate the intracellular milieu of macrophage phagosomes. The protective mAbs to histone $2 \mathrm{~B}$ and Hsp60 enhance macrophage fungistatic/fungicidal responses, subverted $H$. capsulatum's ability to modify the phagosomal environment, resulting in augmented antigen processing and $\mathrm{T}$ cell activation, and control of the fungal disease. The opsonization by the antibody on $H$. capsulatum can also impact the fungus' ability to traffic surface proteins. Future research is needed to better characterize the fundamental influences on protection of antibody in histoplasmosis, including defining the importance of isotype on the protective efficacy, determining the role of the quantity of surface antigen on protection, and the direct effect of antibody on $H$. capsulatum transcriptional regulation.

In addition to exploring fungal antigens as targets for antibody therapy, we have examined the impact of antibody on host cell co-stimulation as a new alternative for controlling the pathogenesis of histoplasmosis. We determined that $H$. capsulatum 

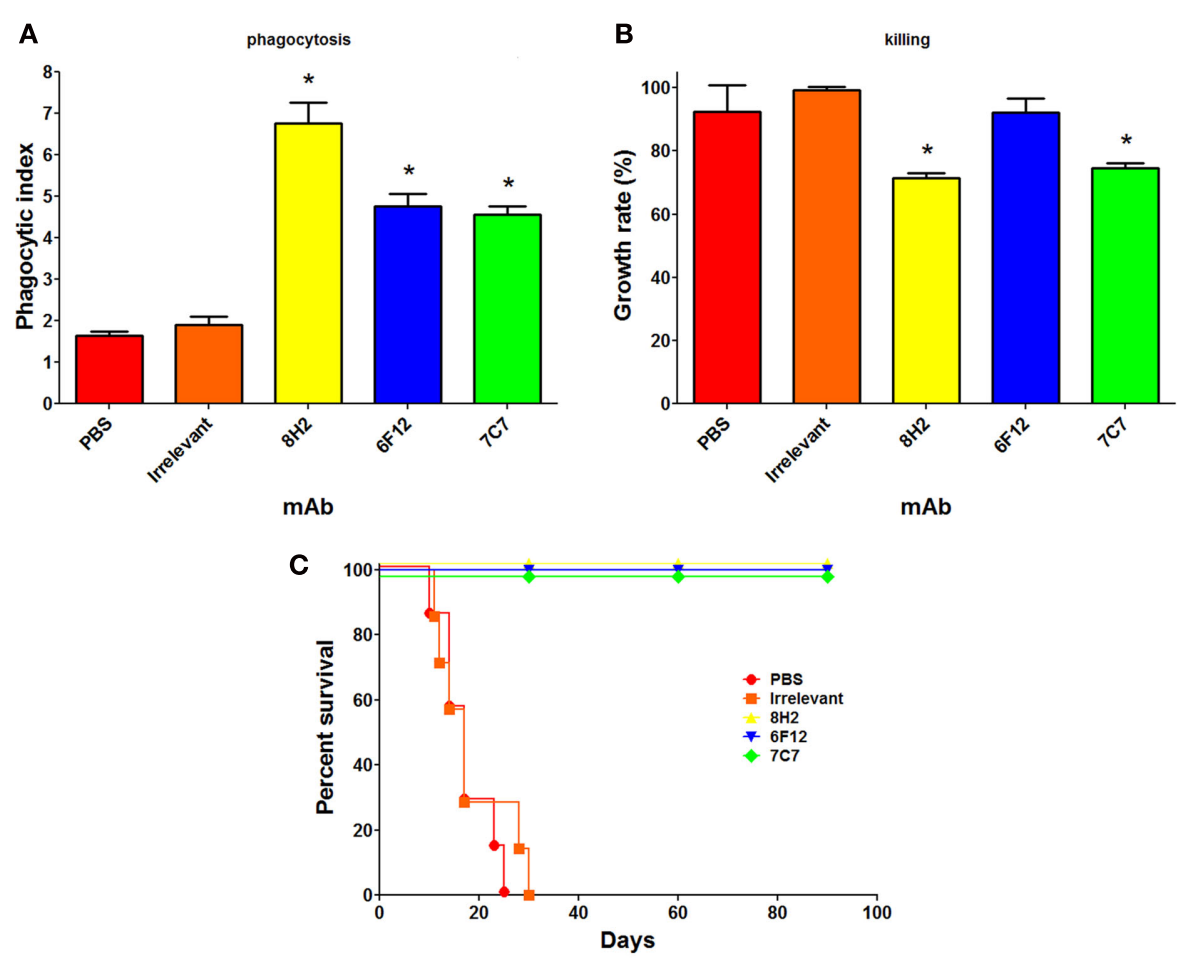

FIGURE 2 | Monoclonal antibodies (mAbs) to the M antigen can modify the pathogenesis of experimental histoplasmosis. The generation of the mAbs is described in Guimaraes et al. (2008). The mAbs produced are mAb 7C7 (IgM isotype), mAb 6F12 (IgG2a), and mAb 8H2 (lgG2a). Using methods described in Guimaraes et al. (2011b), the phagocytosis rates (A), and killing capacity (B) of J774.16 macrophage-like cells reveal that the mAbs significantly enhanced the uptake of yeast cells by the phagocytes $(p<0.05$ vs. controls) and that two of the three mAbs enabled the killing of yeast cells by the $\mathrm{J} 774.16$ cells ( $p<0.05$ for mAbs $8 \mathrm{H} 2$ and $7 \mathrm{C} 7$ vs. controls). (C) C57BI/6 mice infected with $1.25 \times 10^{7}$ opsonized yeast cells had a $100 \%$ survival whereas control infected mice died within 1 month after infection ( $p<0.001$ for mAbs 8H2, 6F12, and 7C7 vs. controls).

altered the PD-L expression on macrophages, which resulted in a dysregulation of T cell activation (Lazar-Molnar et al., 2008). The PD-1/PD-L pathway is involved in maintenance of self-tolerance and $\mathrm{T}$ cell regulation. Mice deficient in $\mathrm{PD}-1$ were protected

\section{REFERENCES}

Allen, H. L., and Deepe, G. S. Jr. (2006). $\mathrm{B}$ cells and CD4-CD8-T cells are key regulators of the severity of reactivation histoplasmosis. J. Immunol. 177, 1763-1771.

Allendoerfer, R., Biovin, G. P., and Deepe, G. S. Jr. (1997). Modulation of immune responses in murine pulmonary histoplasmosis. J. Infect. Dis. 175, 905-914.

Allendorfer, R., Brunner, G. D., and Deepe, G. S. Jr. (1999). Complex requirements for nascent and memory immunity in pulmonary histoplasmosis. J. Immunol. 162, 7389-7396.

Alteras, I. (1966). First Romanian isolation of Histoplasma capsulatum from the soil. Dermatol. Int. 5, 69-71.

Bradsher, R. W. (1996). Histoplasmosis and blastomycosis. Clin. Infect. Dis. 22, S102-S111.
Briles, D. E., Crain, M. J., Gray, B. M., Forman, C., and Yother, J. (1992a). Strong association between capsular type and virulence for mice among human isolates of Streptococcus pneumoniae. Infect. Immun. 60, 111-116.

Briles, D. E., Forman, C., and Crain, M. (1992b). Mouse antibody to phosphocholine can protect mice from infection with mouse-virulent human isolates of Streptococcus pneumoniae. Infect. Immun. 60, 1957-1962.

Cain, J. A., and Deepe, G. S. Jr. (1998). Evolution of the primary immune response to Histoplasma capsulatum in murine lung. Infect. Immun. 66, 1473-1481.

Casadevall, A. (1998). Antibodymediated protection against intracellular pathogens. Trends Microbiol. 6, 102-107.

against lethal challenges of $H$. capsulatum. Administration of $\mathrm{mAb}$ that blocks PD-1 similarly protected wild-type mice against lethal infection. Hence, antibody targeting host responses can modify histoplasmosis.

Casadevall, A., Cassone, A., Bistoni, F., Cutler, J. E., Magliani, W., Murphy, J. W., Polonelli, L., and Romani, L. (1998). Antibody and/or cell-mediated immunity, protective mechanisms in fungal disease: an ongoing dilemma or an unnecessary dispute? Med. Mycol. 36(Suppl. 1), 95-105.

Chandler, J. W. Jr., Smith, T. K., Newberry, W. M. Jr., Chin, T. D., and Kirkpatrick, C. H. (1969). Immunology of the mycoses. II. Characterization of the immunoglobulin and antibody responses in histoplasmosis. J. Infect. Dis. 119, 247-254.

Chu, J. H., Feudtner, C., Heydon, K., Walsh, T. J., and Zaoutis, T. E. (2006). Hospitalizations for endemic mycoses: a populationbased national study. Clin. Infect. Dis. 42, 822-825.
Darling, S. T. (1906). A protozoan general infection producing pseudotubercles in the lungs and focal necrosis in the liver, spleen and lymph nodes. J. Am. Med. Assoc. 46, 1283-1285.

Deepe, G. S. Jr. (2005). Modulation of infection with Histoplasma capsulatum by inhibition of tumor necrosis factor-alpha activity. Clin. Infect. Dis. 41(Suppl. 3), S204-S207.

Deepe, G. S. Jr., Gibbons, R., Brunner, G. D., and Gomez, F. J. (1996). A protective domain of heat-shock protein 60 from Histoplasma capsulatum. J. Infect. Dis. 174, 828-834.

Deepe, G. S. Jr., and Gibbons, R. S. (2002). Cellular and molecular regulation of vaccination with heat shock protein 60 from Histoplasma capsulatum. Infect. Immun. 70, 3759-3767. 
Deepe, G. S. Jr., Gibbons, R. S., and Smulian, A. G. (2008). Histoplasma capsulatum manifests preferential invasion of phagocytic subpopulations in murine lungs. J. Leukoc. Biol. 84, 669-678.

Deepe, G. S. Jr., Smelt, S., and Louie, J. S. (2005). Tumor necrosis factor inhibition and opportunistic infections. Clin. Infect. Dis. 41(Suppl. 3), S187-S188.

Disalvo, A. F., Bigler, W. J., Ajello, L., Johnson, J. E., and Palmer, J. (1970). Bat and soil studies for sources of histoplasmosis in Florida. Public Health Rep. 85, 1063-1069.

Dodd, K., and Thompkins, E. H. (1934). Case of histoplasmosis of darling in a infant. Am. J. Trop. Med. Hyg. 14, 127-137.

Domer, J. E. (1971). Monosaccharide and chitin content of cell walls of Histoplasma capsulatum and Blastomyces dermatitidis. J. Bacteriol. 107, 870-877.

Dromer, F., Charreire, J., Contrepois, A., Carbon, C., and Yeni, P. (1987). Protection of mice against experimental cryptococcosis by anti-Cryptococcus neoformans monoclonal antibody. Infect. Immun. 55, 749-752.

Edwards, L. B., Acquaviva, F. A., Livesay, V. T., Cross, F. W., and Palmer, C. E. (1969). An atlas of sensitivity to tuberculin, PPD-B, and histoplasmin in the United States. Am. Rev. Respir. Dis. 99(Suppl.), 1-132.

Eissenberg, L. G., and Goldman, W. E. (1987). Histoplasma capsulatum fails to trigger release of superoxide from macrophages. Infect. Immun. $55,29-34$.

Emmons, C. W. (1950). Histoplasmosis: animal reservoirs and other sources in nature of the pathogenic fungus Histoplasma capsulatum. Am. J. Public Health 40, 436-440.

Emmons, C. W. (1956a). Histoplasmosis in animals. Public Health Monogr. 70, 272-273.

Emmons, C. W. (1956b). Isolation of Histoplasma capsulatum from soil. Public Health Monogr. 70, 237-239.

Emmons, C. W., Klite, P. D., Baer, G. M., and Hill, W. B. Jr. (1966). Isolation of Histoplasma capsulatum from bats in the United States. Am. J. Epidemiol. 84, 103-109.

Fojtasek, M. F., Kleiman, M. B., Connolly-Stringfield, P., Blair, R., and Wheat, L. J. (1994). The Histoplasma capsulatum antigen assay in disseminated histoplasmosis in children. Pediatr. Infect. Dis. J. 13, 801-805.

Fojtasek, M. F., Sherman, M. R., Garringer, T., Blair, R., Wheat, L. J., and Schnizlein-Bick, C. T. (1993).
Local immunity in lung-associated lymph nodes in a murine model of pulmonary histoplasmosis. Infect. Immun. 61, 4607-4614.

Gomez, B. L., Figueroa, J. I., Hamilton, A. J., Diez, S., Rojas, M., Tobon, A., Restrepo, A., and Hay, R. J. (1999). Detection of the 70kilodalton Histoplasma capsulatum antigen in serum of histoplasmosis patients: correlation between antigenemia and therapy during followup. J. Clin. Microbiol. 37, 675-680.

Gomez, B. L., Figueroa, J. I., Hamilton, A. J., Ortiz, B. L., Robledo, M. A., Restrepo, A., and Hay, R. J. (1997). Development of a novel antigen detection test for histoplasmosis. J. Clin. Microbiol. 35, 2618-2622.

Goodwin, R. A. Jr., and Des Prez, R. M. (1978). State of the art: histoplasmosis. Am. Rev. Respir. Dis. 117, 929-956.

Goodwin, R. A., Loyd, J. E., and Des Prez, R. M. (1981). Histoplasmosis in normal hosts. Medicine (Baltimore) 60, 231-266.

Guimaraes, A. J., Frases, S., Gomez, F. J., Zancope-Oliveira, R. M., and Nosanchuk, J. D. (2009). Monoclonal antibodies to heat shock protein 60 alter the pathogenesis of Histoplasma capsulatum. Infect. Immun. 77, 1357-1367.

Guimaraes, A. J., Hamilton, A. J., De, M. G. H. L., Nosanchuk, J. D., and Zancope-Oliveira, R. M. (2008). Biological function and molecular mapping of $\mathrm{M}$ antigen in yeast phase of Histoplasma capsulatum. PLoS ONE 3, e3449. doi:10.1371/journal.pone.0003449

Guimaraes, A. J., Frases, S., Pontes, B., De Cerqueira, M. D., Rodrigues, M. L., Viana, N. B., Nimrichter, L., and Nosanchuk, J. D. (2011a). Agglutination of Histoplasma capsulatum by IgG monoclonal antibodies against Hsp60 impacts macrophage effector functions. Infect. Immun. 79, 918927.

Guimaraes, A. J., Martinez, L. R., and Nosanchuk, J. D. (2011b). Passive administration of monoclonal antibodies against $H$. capsulatum and other fungal pathogens. J. Vis. Exp. doi:10.3791/2532. Available at: http://www.ncbi.nlm.nih.gov/ entrez/query.fcgi? $\mathrm{cmd}=$ Retrieve $\&$ $\mathrm{db}=$ PubMed\&dopt=Citation \& list_uids $=21372781$

Guimaraes, A. J., Nakayasu, E. S., Sobreira, T. J., Cordero, R. J., Nimrichter, L., Almeida, I. C., and Nosanchuk, J. D. (2011c). Histoplasma capsulatum heat-shock 60 orchestrates the adaptation of the fungus to temperature stress. PLoS
ONE 6, e14660. doi:10.1371/journal.pone.0014660

Guimaraes, A. J., Nosanchuk, J. D., and Zancope-Oliveira, R. M. (2006). Diagnosis of histoplasmosis. Braz. J. Microbiol. 37, 1-13.

Habich, C., Kempe, K., Gomez, F. J., Lillicrap, M., Gaston, H., Van der Zee, R., Kolb, H., and Burkart, V. (2006). Heat shock protein 60: identification of specific epitopes for binding to primary macrophages. FEBS Lett. 580, 115-120.

Huffnagle, G. B., and Deepe, G. S. (2003). Innate and adaptive determinants of host susceptibility to medically important fungi. Curr. Opin. Microbiol. 6, 344-350.

Isbister, J., Elliott, M., and Nogrady, S. (1976). Histoplasmosis: an outbreak occurring among young men who visited one cave. Med. J. Aust. 2, 243-248.

Kasuga, T., White, T. J., Koenig, G., Mcewen, J., Restrepo, A., Castaneda, E., Da Silva Lacaz, C., Heins-Vaccari, E. M., De Freitas, R. S., ZancopeOliveira, R. M., Qin, Z., Negroni, R., Carter, D. A., Mikami, Y., Tamura, M., Taylor, M. L., Miller, G. F., Poonwan, N., and Taylor, J. W. (2003). Phylogeography of the fungal pathogen Histoplasma capsulatum. Mol. Ecol. 12, 3383-3401.

Kauffman, C. A. (2007). Histoplasmosis: a clinical and laboratory update. Clin. Microbiol. Rev. 20, 115-132.

Kozel, T. R., and McGaw, T. G. (1979) Opsonization of Cryptococcus neoformans by human immunoglobulin G: role of immunoglobulin G in phagocytosis by macrophages. Infect. Immun. 25, 255-261.

Lazar-Molnar, E., Gacser, A., Freeman, G. J., Almo, S. C., Nathenson, S. G., and Nosanchuk, J. D. (2008). The PD-1/PD-L costimulatory pathway critically affects host resistance to the pathogenic fungus Histoplasma capsulatum. Proc. Natl. Acad. Sci. U.S.A. 105, 2658-2663.

Lendvai, N., and Casadevall, A. (1999). Monoclonal antibody-mediated toxicity in Cryptococcus neoformans infection: mechanism and relationship to antibody isotype. J. Infect. Dis. 180, 791-801.

Limaye, A. P., Connolly, P. A., Sagar, M., Fritsche, T. R., Cookson, B. T., Wheat, L. J., and Stamm, W. E. (2000). Transmission of Histoplasma capsulatum by organ transplantation. N. Engl. J. Med. 343, 1163-1166.

Lockhart, S. R., Diekema, D. J., and Pfaller, M. A. (2009). "The epidemiology of fungal infections," in Clinical Mycology, eds E. J. Anaissie,
M. R. McGinnis, and M. A. Pfaller (Oxford: Elsevier Inc.)

Long, K. H., Gomez, F. J., Morris, R. E., and Newman, S. L. (2003) Identification of heat shock protein 60 as the ligand on Histoplasma capsulatum that mediates binding to CD18 receptors on human macrophages. J. Immunol. 170, 487-494.

Lopes, L. C., Guimaraes, A. J., De Cerqueira, M. D., Gomez, B. L., and Nosanchuk, J. D. (2010). A Histoplasma capsulatum-specific IgG1 isotype monoclonal antibody, $\mathrm{H} 1 \mathrm{C}$, to a 70-kilodalton cell surface protein is not protective in murine histoplasmosis. Clin. Vaccine Immunol. 17, 1155-1158.

Louria, D. B., and Kaminski, T. (1965). Passively-acquired immunity in experimental cryptococcosis. Sabouraudia 4, 80-84.

Maresca, B., and Kobayashi, G. S. (1989). Dimorphism in Histoplasma capsulatum: a model for the study of cell differentiation in pathogenic fungi. Microbiol. Rev. 53, 186-209.

Marques, M. A. M., Mahapatra, S., Nandan, D., Dick, T., Sarno, E. N., and Pessolani, M. C. V. (2000). Bacterial and host-derived cationic proteins bind a2-laminins and enhance Mycobacterium leprae attachment to human Schwann cells. Microbes Infect. 2, 1407-1417.

Marques, M. A. M., Mahapatra, S., Sarno, E. N., Santos, S., Spencer, J. S. Brennan, P. J., and Pessolani, M. C. V. (2001). Further biochemical characterization of Mycobacterium leprae laminin-binding proteins. Braz. J. Med. Biol. Res. 34, 463-470.

Martinez, L. R., Mihu, M. R., Gacser, A., Santambrogio, L., and Nosanchuk, J. D. (2009). Methamphetamine enhances histoplasmosis by immunosuppression of the host. J. Infect. Dis. 200, 131-141.

Medoff, G., Kobayashi, G. S., Painter, A., and Travis, S. (1987). Morphogenesis and pathogenicity of Histoplasma capsulatum. Infect. Immun. 55, 1355-1358.

Meloan, E. L. (1952). Histoplasmosis. Miss. Doct. 29, 256-257.

Mukherjee, J., Nussbaum, G., Scharff, M. D., and Casadevall, A. (1995a). Protective and nonprotective monoclonal antibodies to Cryptococcus neoformans originating from one $\mathrm{B}$ cell. J. Exp. Med. 181, 405-409.

Mukherjee, J., Scharff, M. D., and Casadevall, A. (1995b). Variable efficacy of passive antibody administration against diverse Cryptococcus neoformans strains. Infect. Immun. 63, 3353-3359. 
Mukherjee, J., Scharff, M. D., and Casadevall, A. (1992). Protective murine monoclonal antibodies to Cryptococcus neoformans. Infect. Immun. 60, 4534-4541.

Newman, S. L. (2005). Interaction of Histoplasma capsulatum with human macrophages, dendritic cells, and neutrophils. Methods Mol. Med. 118, 181-191.

Nimrichter, L., Rodrigues, M. L., Rodrigues, E. G., and Travassos, L. R. (2005). The multitude of targets for the immune system and drug therapy in the fungal cell wall. Microbes Infect. 7, 789-798.

Nosanchuk, J. D., Gomez, B. L., Youngchim, S., Diez, S., Aisen, P., Zancope-Oliveira, R. M., Restrepo, A., Casadevall, A., and Hamilton, A. J. (2002). Histoplasma capsulatum synthesizes melanin-like pigments in vitro and during mammalian infection. Infect. Immun. 70, 5124-5131.

Nosanchuk, J. D., Steenbergen, J. N., Shi, L., Deepe, G. S. Jr., and Casadevall, A. (2003). Antibodies to a cell surface histone-like protein protect against Histoplasma capsulatum. J. Clin. Invest. 112, 1164-1175.

Pessolani, M. C., Hunter, S. W., and Brennan, P. J. (1993). Relationship between host histones and armadillo-derived Mycobacterium leprae. Int. J. Lepr. Other Mycobact. Dis. 61, 381-388.

Pethe, K., Puech, V., Daffe, M., Josenhans, C., Drobecq, H., Locht, C., and Menozzi, F. D. (2001). Mycobacterium smegmatis lamininbinding glycoprotein shares epitopes with Mycobacterium tuberculosis heparin-binding haemagglutinin. Mol. Microbiol. 39, 89-99.

Pfaller, M. A., and Diekema, D. J. (2010). Epidemiology of invasive mycoses in North America. Crit. Rev. Microbiol. $36,1-53$.

Pirofski, L. A., and Casadevall, A. (1996). Cryptococcus neoformans: paradigm for the role of antibody immunity against fungi? Zentralbl. Bakteriol. $284,475-495$.
Pizzini, C. V., Zancope-Oliveira, R. M., Reiss, E., Hajjeh, R., Kaufman, L., and Peralta, J. M. (1999). Evaluation of a western blot test in an outbreak of acute pulmonary histoplasmosis. Clin. Diagn. Lab. Immunol. 6, 20-23.

Prado, M., Silva, M. B., Laurenti, R., Travassos, L. R., and Taborda, C. P. (2009). Mortality due to systemic mycoses as a primary cause of death or in association with AIDS in Brazil: a review from 1996 to 2006. Mem. Inst. Oswaldo Cruz 104, 513-521.

Saliba, A., and Beatty, O. A. (1960). Pulmonary histoplasmosis, importance of diagnostic methods, with report of an early case. JAMA 173, 902-904.

San-Blas, G., Ordaz, D., and Yegres, F. J. (1978). Histoplasma capsulatum: chemical variability of the yeast cell wall. Sabouraudia 16, 279-284.

Sau, K., Mambula, S. S., Latz, E., Henneke, P., Golenbock, D. T., and Levitz, S. M. (2003). The antifungal drug amphotericin B promotes inflammatory cytokine release by a Tolllike receptor- and CD14-dependent mechanism. J. Biol. Chem. 278, 37561-37568.

Scheckelhoff, M., and Deepe, G. S. Jr. (2002). The protective immune response to heat shock protein 60 of Histoplasma capsulatum is mediated by a subset of V beta $8.1 / 8.2+$ T cells. J. Immunol. 169, 5818-5826.

Scheckelhoff, M., and Deepe, G. S. Jr. (2005). A deficiency in gamma interferon or interleukin-10 modulates T-cell-dependent responses to heat shock protein 60 from Histoplasma capsulatum. Infect. Immun. 73, 2129-2134.

Shi, L., Albuquerque, P. C., LazarMolnar, E., Wang, X., Santambrogio, L., Gacser, A., and Nosanchuk, J. D. (2008). A monoclonal antibody to Histoplasma capsulatum alters the intracellular fate of the fungus in murine macrophages. Eukaryot. Cell 7, 1109-1117.

Shimoji, Y., Ng, V., Matsumura, K., Fischetti, V. A., and Rambukkana, A. (1999). A 21-kDa surface protein of Mycobacterium leprae binds peripheral nerve laminin-2 and mediates Schwann cell invasion. Proc. Natl. Acad. Sci. U.S.A. 96, 9857-9862.

Smith, C. D. (1971a). "Nutritional factors that are required for the growth and sporulation of Histoplasma capsulatum," in Histoplasmosis: Proceedings of the Second National Conference, eds L. Ajello, E. W. Chick, and M. L. Furcolow (Springfield: C. Thomas), 64-70.

Smith, C. D. (1971b). "The role of birds in the ecology of Histoplasma capsulatum," in Histoplasmosis: Proceed ings of the Second National Conference, eds L. Ajello, E. W. Chick, and M. L. Furcolow (Springfield: C. Thomas), 140-148.

Strasser, J. E., Newman, S. L., Ciraolo, G. M., Morris, R. E., Howell, M. L., and Dean, G. E. (1999). Regulation of the macrophage vacuolar ATPase and phagosome-lysosome fusion by Histoplasma capsulatum. J. Immunol. 162, 6148-6154.

Taborda, C. P., and Casadevall, A. (2001). Immunoglobulin M efficacy against Cryptococcus neoformans: mechanism, dose dependence, and prozone-like effects in passive protection experiments. J. Immunol. 166, 2100-2107.

Taborda, C. P., Rivera, J., Zaragoza, O., and Casadevall, A. (2003). More is not necessarily better: prozonelike effects in passive immunization with IgG. J. Immunol. 170, 3621-3630.

Tewari, R. P., Sharma, D., Solotorovsky, M., Lafemina, R., and Balint, J. (1977). Adoptive transfer of immunity from mice immunized with ribosomes or live yeast cells of Histoplasma capsulatum. Infect. Immun. 15, 789-795.

Vecchiarelli, A., and Casadevall, A. (1998). Antibody-mediated effects against Cryptococcus neoformans: evidence for interdependency and collaboration between humoral and cellular immunity. Res. Immunol. 149, 321-333

Wheat, L. J., Freifeld, A. G., Kleiman, M. B., Baddley, J. W., Mckinsey, D. S., Loyd, J. E., and Kauffman, C.
A. (2007). Clinical practice guidelines for the management of patients with histoplasmosis: 2007 update by the Infectious Diseases Society of America. Clin. Infect. Dis. 45, 807-825.

Wheat, L. J., and Kauffman, C. A. (2003). Histoplasmosis. Infect. Dis. Clin. North Am. 17, 1-19.

Yuan, R. R., Casadevall, A., Oh, J., and Scharff, M. D. (1997). T cells cooperate with passive antibody to modify Cryptococcus neoformans infection in mice. Proc. Natl. Acad. Sci. U.S.A. 94, 2483-2488.

Zaragoza, O., Alvarez, M., Telzak, A., Rivera, J., and Casadevall, A. (2007). The relative susceptibility of mouse strains to pulmonary Cryptococcus neoformans infection is associated with pleiotropic differences in the immune response. Infect. Immun. 75, 2729-2739.

Zeidberg, L. D., Ajello, L., Dillon, A., and Runyon, L. C. (1952). Isolation of Histoplasma capsulatum from soil. Am. J. Public Health 42, 930-935.

Conflict of Interest Statement: The authors declare that the research was conducted in the absence of any commercial or financial relationships that could be construed as a potential conflict of interest.

Received: 15 November 2011; accepted: 12 January 2012; published online: 02 February 2012.

Citation: Nosanchuk JD, ZancopéOliveira RM, Hamilton AJ and Guimarães AJ (2012) Antibody therapy for histoplasmosis. Front. Microbio. 3:21. doi: 10.3389/fmicb.2012.00021

This article was submitted to Frontiers in Fungi and Their Interactions, a specialty of Frontiers in Microbiology.

Copyright () 2012 Nosanchuk, ZancopéOliveira, Hamilton and Guimarães. This is an open-access article distributed under the terms of the Creative Commons Attribution Non Commercial License, which permits non-commercial use, distribution, and reproduction in other forums, provided the original authors and source are credited. 